\title{
Afro-Latin American Documentary Resistance from the Pacific Coast: How Voces de Resistencia (2017) Changes the Landscapes of Aesthetics, Academia/Community Collaboration, and Black Feminist Activism During the Colombian "Peace Process” Peruvian Government
}

\author{
Sarah Ohmer • Lehman College - CUNY
}

\begin{abstract}
Voces de Resistencia, Capítulo 1, is a short documentary film with an original soundtrack composed and performed by Black Colombian female folk a cappella chorus, or alabadoras. The multimedia product makes use of Black feminist pedagogy and resistance: it portrays a silenced and oppressed group in Bojayá, Colombia. The focus on alabadoras singers and composers promotes self-definition and exposes the power of self-determination in songwriting, an a cappella chorus performance, and documentary filmmaking.
\end{abstract}

$\mathrm{T}$ he following analysis of the documentary Voces de Resistencia, Capitulo 1, presents the film as a holistic and Black Feminist project as well as the product of transnational community building. The multimedia project connects a small group of Afro-Colombian women with U.S.based Ford Foundation and Cali-based Center for African Diaspora studies (CEAF). The production process includes the singer-songwriters' experiences and perspectives, and the finished product represents their authentic worldview as survivors of guerrilla warfare, deterritorialization, forced displacement, as capable of healing themselves and communities via song. The analysis of the film focuses on the aesthetic and the production of the multimedia project. I argue that Voces de Resistencia: Capitulo 1, as a film and as a community-building project, offers four contributions to Afro-Latinx cinema and Afro-Latin American Studies: 1) a method for documentary production infused with Afro-Latin American Studies and Black Feminist concepts of self-determination (Butler 1998 5, Hill Collins 2000; 3-5), intellectual work and self-definition (Hill Collins 2000 xiii), and Afrodiasporic conspiracy (Figueroa Vergara 2017); 2) a documentary film aesthetic centered on Blackness, femininity, and ritual; 3) an audiovisual cinematic witnessing that aims to heal communal trauma; 4) an example of community building that includes a) the Pacific Coast residents who were displaced and massacred during the war, b) the Cali, Colombia ICESI University's Center for Afrodiasporic Studies (CEAF), and c) grant institutions in Colombia and abroad such as the Ford Foundation. Throughout the article, I include anecdotes from project director Aurora Vergara Figueroa to illustrate how one can make use of U.S. funded federal grants to build transnational networks for the self-representation of Black women in Afro-Latinx cinema.

\section{The Black (Media) Colombian Revolution}

At the time of writing this article, Colombia is making headlines on PBS Newshour, for being the nation with the most disappeared individuals in the world (April 29, 2019 episode). And yet, the reality of the impact remains unseen on many Latin-American news channels, while the current intellectual, political, and artistic Black Colombian revolution, remains suppressed (Vergara Figueroa et al. 14 2017; Chaves Maldonado 19). ${ }^{1}$ The systemic oppressions manifest in racialized geographies as well, with the Pacific demonstrably one of the poorest regions of Colombia, a reality which, some will argue, demands reparations (Mosquera 
Rosabo-Labbé et al. 17), and presents an urgent national and global situation of genocide wherein Black Colombians have been disconnected from their native Colombian lands, and their ancestral knowledges (Arboleda Quiñones 474).

The genocide of Colombians of African Descent is the focus of Sociologist Santiago de Arboleda at the Universidad Andina in Ecuador, who recently presented his findings on qualifying the violence against communities of African descent as genocide, at the "Empire and its Aftermath" Conference at the University of Pittsburgh (April 3-5, 2019). At the same time, Colombia is witnessing a boom of intellectual production by scholars of African descent, including but not limited to the 2018 publication of Demando mi Libertad!, an edited volume on the agency and resistance of Black Colombian women in the 16th century, and on the importance of archival research by women of African descent in the 21st century, some of them descendants of palenqueras - or African descended women who established communities independent of the plantation economy-women from maroon communities. Descolonizando mundos, published in 2017, also edited by Aurora Vergara Figueroa, is an anthology of scholarly publications by intellectuals of African descent from Colombia representing multiple disciplines in the social sciences, humanities, and the arts.

In this context of Afro-descended intellectual resistance, Ladino state mandated political violence, and centuries-long Black revolution, the civil war against communities of African descent has not ended. The term Ladino is used in Colombia to refer to a section of the population that has overtime been favored with the bulk of the economic wealth and governmental power. Originally supported by the Spanish during the colonial era, and then referred to as "Criollo" or Spaniards born in the Americas, today the Ladino population is the sector that does not identify as Black or Indigenous and typically lives in/is from the better served topographical and geographical parts of Colombia - the plateaus and valleys such as Bogotá, Manizales, etc. One would add that in this context, the Black Colombian Revolution would not be televised. Yet, here comes Voces de Resistencia, Capitulo 1. The multimedia, institutional, and communal project circulates as a YouTube televised documentary, also available in DVD format, with a 12-song LP of the traditional Afro-descended a cappella singing group Alabadora. The documentary depicts Black intellectual and artistic resistance, denounces state mandated violence and its cruel, deadly impact on African descended groups in Colombia, and foregrounds the Black revolution that unfolds in our sisters' communities on the Pacific Coast.

\section{A Claim to Epistemic Justice, or \#elpueblonoserindecarajo}

Halfway into the United Nations' International Decade for People of African descent, a few years into the Colombian Peace Process, and one year after the presidential elections in Colombia, this project puts the Colombian Pacific Coast's Black subjectivities at the center, as they stand behind and in front of the camera, and use U.S. Federal grants and Colombian institutional grants to self-represent and defend peace in the Pacific Coast in song, cinematography, and healing ritual.

Voces de Resistencia Capitulo 1: Cantadoras del Pogue (2017), directed by José Varón, with general coordination by Aurora Vergara Figueroa, Lina Jaramillo López, and Lina Mosquera Lemus, involved a large team of African descended faculty and students in the Center for African Diaspora Studies at the University of ICESI in Cali, Colombia, and was partially produced in the kitchens of the mothers and daughters of the Quibdó community and other towns. The 25-minute short documentary film is audiovisual proof that the people will not give up, like their hashtag states unapologetically.

Live sound editor Mario Hernández, drone camera director Jairo Rodríguez, and film editor Federico Castañeda frame the documentary with cricket sounds on a black background, with a logo created by the community of women represented in the film, designed by María Paola Herrera Valencia. A brief script description of how the film came to fruition follows.

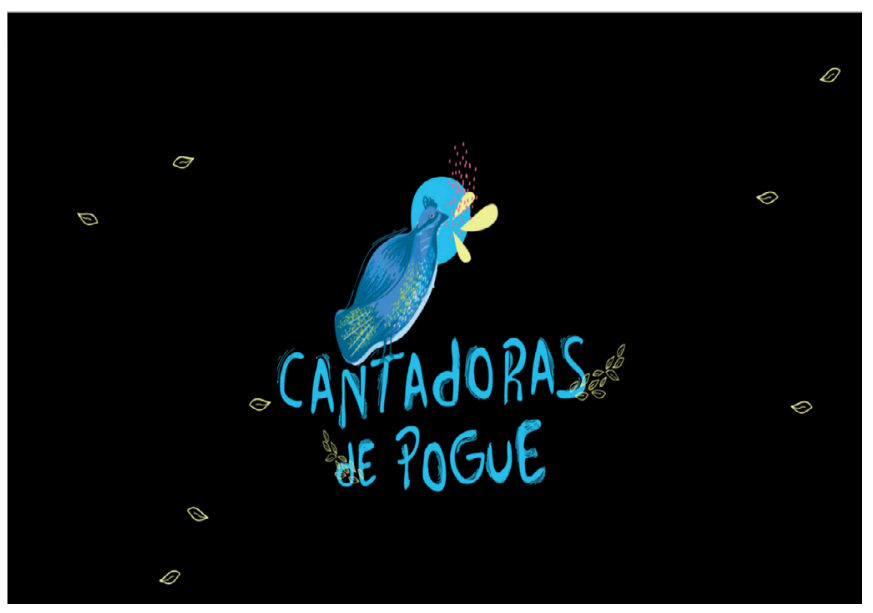

In the first few seconds of the film, a tranquil sound accompanies a crisp and colorful logo of a blue bird, and an inscription that connects the University ICESI of Cali, the Ford Foundation, the group of alabadoras and alabadores of Pogue, the province of Bojayá, and the region of Chocó. Script on the screen describes that this is an audiovisual project which includes a 12-song LP, and presents the film as a documentary featuring some of the songs and some interviews. A time stamp appears: February-December 2016. 


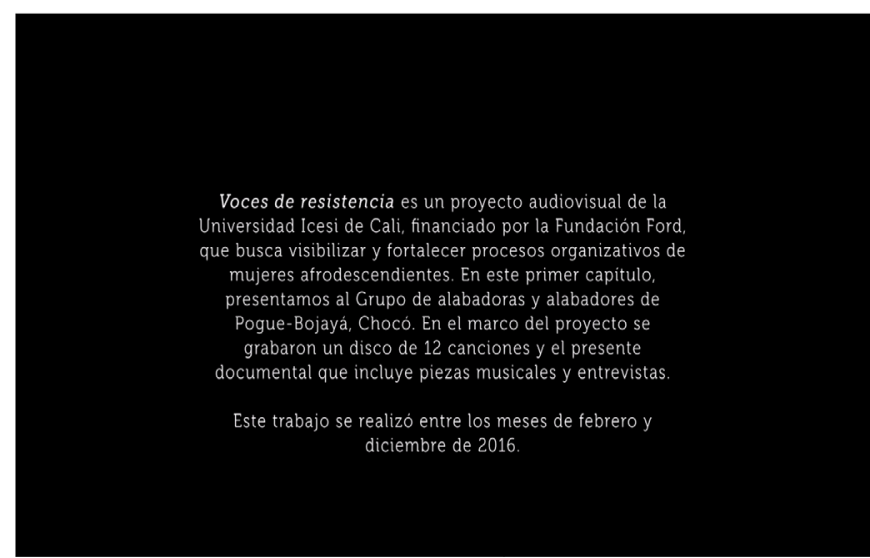

To gain more context on the making of the short documentary film, I interviewed Dr. Vergara Figueroa, Director of the Center for Africana Research at ICESI in Cali, Colombia, in the middle of an afternoon in January 2019. There were no cicadas, crickets, or frogs that we could hear in the background, though there was sun. We sat on a bench after a long and productive workshop-the Taller Internacional "Praxis de investigación y conexiones transnacionales: estudios afrodescendientes en las Américas" - on the University of Florida campus in Gainesville. I did enjoy the same sounds as in the opening of the documentary, at dusk, overlooking a swamp and watching a bright colored U.S. Southern sunset in Gainesville.

Voces de Resistencia, Aurora Vergara Figueroa explains in the interview, was not originally conceived as a chapter of a larger multimedia project. Unaware of the larger project at the time, the production team had agreed to make this a participatory project. It was imperative, she explains, to involve and tell the stories of Black women who had witnessed the most terrorizing violence in their communities, to tell their stories how they wanted them told, and to say what they wanted to share about their traumas, their resistance, their lives, their lost ones:

Es decir.... este proyecto empezó, eh, Voces de Resistencia inicialmente era un video documental con las mujeres de Pogue, vamos a contar su historia, pero vamos a trabajar con ellas. Para ver qué quieren, cómo sale, cómo se lo imaginan y vamos a ver qué sale. Entonces al principio, lo pensamos como un ejercicio de investigación y acción participativa.

She explained how the project unfolded, and the amount of conversations that were dedicated to ensuring that the production would fit the ethics of the project. The impetus, for Dr. Vergara Figueroa, was epistemic justice. That is to say, it was important to make up for the discursive erasures of Black women's opinions and experiences during the war, and to redress the portrayals of Black women as unworthy or unable to create meaning out of the violence and the lived history. Being a sociologist of African descent from Latin America from a certain part of Colombia whose native language is Spanish, and with extensive research in Black Feminisms and decolonial theory, Vergara Figueroa had not stopped fighting for epistemic justice since she started to participate in the academic world of higher education and social science research, including her graduate studies at the University of Massachusetts in Amherst. She explained her journey to make a case for the importance of epistemic justice in this particular project. As a researcher, editor, Africana studies director, as a daughter and a sister, her purpose was to work with the women: to see what they wanted, for them to see how it came out, how did they picture it, and from there, see what happens. She remembers how, in the beginning, the project was an exercise, that, for her, was an exercise of epistemic justice:

Pero al mismo tiempo lo que usamos en mi caso, creo que era como un tipo de justicia epistémica. Porque yo entré al mundo académico, cuestionándome muchas situaciones que yo veía allí, especialmente la manera en cómo es que se concibe la vida de la gente negra.

In other words, instead of turning to a history that was written by the Ladino Columbian sector, or by individuals and groups typically understood as authoritative experts, and instead of contributing to the erasure of Black women's experiences or the portrayal of Black women as victims or as objects of study, epistemic justice sets the record straight, and describes a community's history from their perspectives, as they are self-represented in a project that became a striking documentary. This article follows this model and strives for epistemic justice, too. With a Black feminist analysis of the documentary, anecdotes include perspectives from project director Aurora Vergara Figueroa on how to successfully produce a documentary with international funding and build transnational networks for self-representation in Afro-Latinx cinema.

With this in mind, the hashtag earns a dimension wherein activist-scholars and scholar-activists can tag the work that they do, not necessarily out in the streets or in strategic meetings. Striving for epistemic justice in collaborative research that leads to self-definition and self-determination is a means of raising our fists in the air too, and another way to mobilize and yell, " thepeoplewillnotgiveupdamnit, \#elpueblonoserindecarajo.”

\section{Black Feminist Self-Determination, Intellectual Work, and Afrodiasporic Conspiracy in Documentary Production}

As an act of epistemic justice, the project invokes the role of the intellectual as Patricia Hill Collins defines it in 
Black Feminist Thought, as any Black woman that has attained an authentic worldview or keen awareness of how oppression affects all of the demographic sectors of society (5-8). Hill Collins teaches that any Black woman who has gone through a process of self-conscious struggle, from a marginal position of society, yet with some access to the dominant sectors of society (as a domestic worker, a student, a professor, etc.) can contribute thought provoking knowledge as an intellectual. Which is to say, any woman of the Quibdó and surrounding communities could provide their take on struggles against injustice, and their understanding, their beliefs, or their episteme, to a larger academic project on Colombian culture and history.

Furthermore, the title of the project could not limit itself to one specific community or problem. It needed to contain more, as Black feminism advocates for multiplicity and heterogeneity, and epistemic justice calls for inclusion regardless of complication. Vergara Figueroa notes how the project developed; as she came back from scout locating and conversations with community members in the Chocó, she recalled being at the airport and, "con el equipo de grabación, esperando allí, se me ocurrió que podríamos hacerlo como una serie; que no solamente contáramos esa historia sino la historia de muchas otras mujeres... en el país y quizás, en la diáspora" (Vergara, 2019 interview). There was more to this one community, and this would be chapter 1; she could continue to tell the stories of Black women and aptly address epistemic injustice through film.

With a few questions to prepare ahead of the interview, Vergara Figueroa reflected on whether one could define the documentary film, or the project overall, as a holistic form of Black feminist intellectual activism. The film puts forth the women of Bojayá as knowledge producing individuals, rather than objects of study, or even subjects who were a part of a study. The alabadoras (singers) play a central role in their community and teach us, the viewers, strategies to heal from collective trauma. The alabao, a traditional song of mourning, borne out of African rituals that remained a practice, a knowledge, and a skill handed down through the generations, are portrayed as a strategy for transgressive resistance (Voces de Resistencia o'o" 47). This is not passive, ornate, folklore; it's a revolutionary weapon.

In the first minute of the documentary, the crickets continue to chirp and the script describing how the Project came about cuts to the title of the documentary:

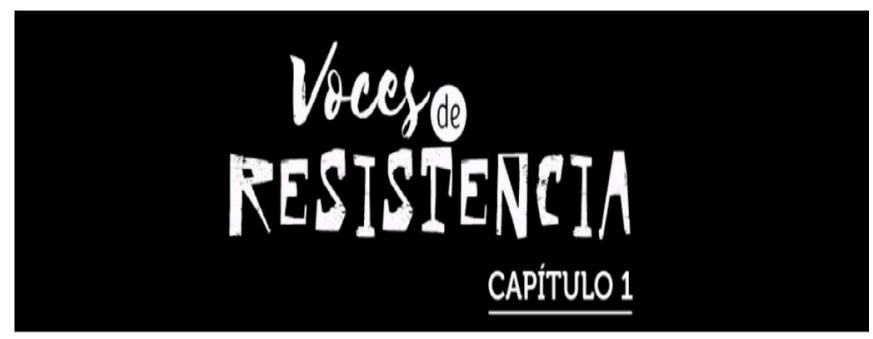

The cicadas and crickets are joined in by frogs, while the image cuts to a map that inscribes the often-overlooked region as front and center to this documentary available on YouTube.

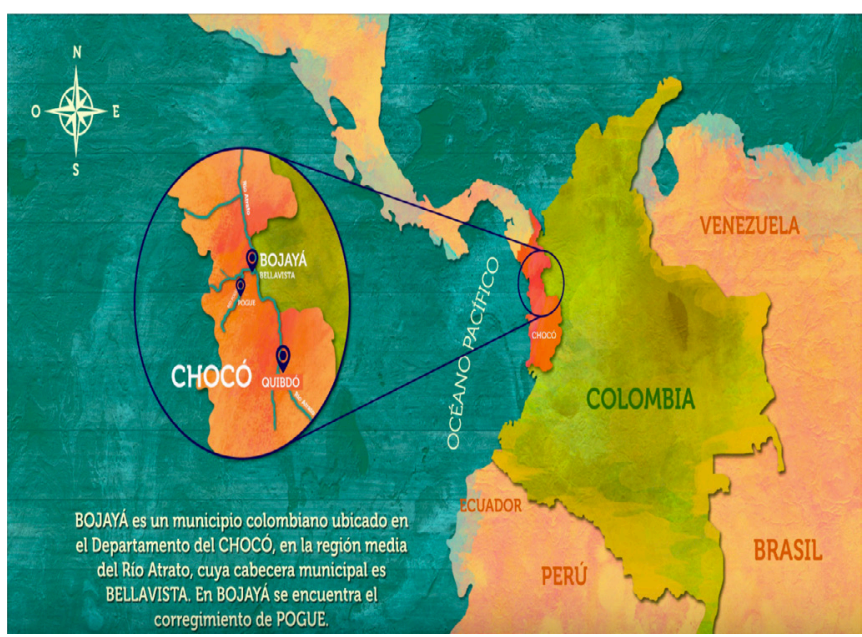

The aesthetic of self-determination in this documentary comes forth in the first minute, first with the bright colored logo. The logo came from a workshop, led by designer Claudia Patricia Buitrago who participated in the project and prompted the women of Bojayá to make their traditional dolls with the documentary production team. The blue bird is a wink to one of the dolls created in the workshop. Selfdetermination from a Black feminist perspective continues with the black and white logo and title of the documentary: Voces de Resistencia, Capítulo 1. The appearance of the title can be read as a reference to one central mode of construction of the documentary. It is created with the idea that this documentary will be the first of many more depicting black women self-defining and self-determining their resistance: "Voices of Resistance, Chapter 1," or the first set of many more voices to come.

When the map cuts in, after the title, the brightest color on the map stands in the middle, and for the Chocó region. The color and centering of the region underline geographic self-determination in the film. The design of the cut out brings the Chocó to the forefront, and officially front and center, to frame the thematic self-determination in the film. In this powerful image, a literal act of self-definition adds to the self-determination.

A note in the bottom left, contrasted with the Pacific Ocean in the background-not a coincidental placementdescribes the region that rarely comes with a definition: Bojayá is a Colombian town located in the district of Chocó, in the central area of the Atrato River, where Bellavista is the main township. The "corregimiento de Pogue" is located in Bojayá. Notice how all of the geographic points are in all caps. This map remains on the screen for 10 seconds, with crickets, and more frogs, as the sound in the background. 
The alabaos make possible the witnessing of a traumatic event. With their songs, what happened is named, denounced, and with this witnessing, healing can occur; healing from traumas such as the bombing of the Pablo Apóstol church, where dozens of families that had taken refuge from the civil war were massacred by a cylinder bomb dropped in a church that was clearly a civilian refuge. 70 community members, including 46 children, died in the Iglesia Pablo Apóstol. This happened on May 2, 2002, during a face-off between José María Córdoba, of the FARC, and Elmer Cárdenas from the ACCU (Peasants' Self Defense Campaign of Córdoba and Urará) (Voces de Resistencia o'1”).

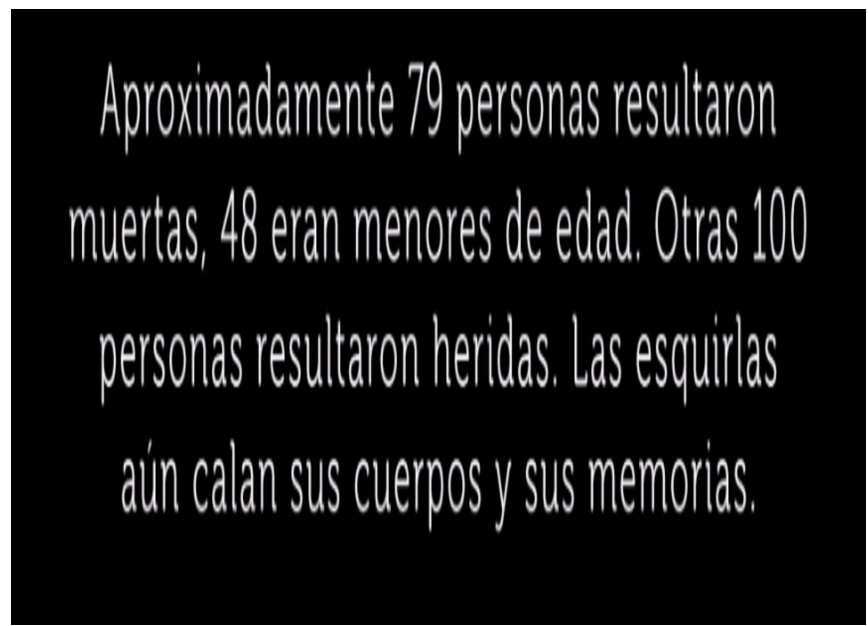

With lyrics that include a connection to Jesus, community's stories, and direct critiques of the paramilitary and guerrillas' gratuitous violence, and with interviews that allow women and men to speak for themselves, the film inspires viewers to learn from, acknowledge, and perceive the Bojayá women as thought-producing individuals, sociologists, peace-makers, conflict negotiators, singers, songwriters, designers, dressmakers, chefs, cooks, and strategists. The alabadoras are intellectuals and healers looking to heal their bodies and their memories. When I asked about how to label the documentary, I suggested if we could call it a Black feminist project of holistic intellectual activism:

Dr. Sarah Soanirina Ohmer: "Quiero hablar del documental o del proyecto-como tu quieras definirlo. ¿Se podría hablar de ello como una obra de activismo intelectual holístico negro feminista?"

Dra. Aurora Vergara Figueroa: "Bueno, creo que es una categoría bastante profunda y creo que pensarlo así nos ayudaría mucho a pensar y a comprender qué fue lo que hicimos."

The Africana studies director from Cali agrees that thinking of the film or project as a "Holistic Black Feminist Intellectual Project" is a profound category that allows one, actually, that helps us, a lot, she says; it helps the research team but also Black feminists and Black women to think about and understand what dynamics were at work during the making of the project.

The project and documentary's focus on alaboas singers and songwriters presents a clear mission to "conspire." To conspire, or conspirando, is a strategy of Afrodiasporic and Black Colombian feminist resistance coined by women of the Chocó in a gathering that led to their manifesto for feminist conspiracy. The poetic justice, the epistemic justice, the cultural justice, and the spiritual renewal, along with the placing of women of African descent and their underrepresented communities as the focus of the camera and the production of the film, make up a work of Afrodiasporic conspiracy.

In the 2016 Latin America-focused issue of Meridians: Transnational Feminisms" "Afrodiasporic Feminist Conspiracy: Motivations and Paths forward from the First International Seminar" article, scholar-activist Katherine Arboleda Hurtado and Vergara Figueroa claim that the "conspiracy started in Cali, Colombia," June 24-25 2011, in the Chontaduro Cultural House, with the women participants of the Universidad del Valle's Afro-Colombian Group (GAUV) and Black women from various cities of Colombia. The Chontaduro Cultural House is a group of independent scholars and activists and a community center or "cultural house" in the historically and predominantly Black district of Aguablanca, in Cali. The group hosted the conference, where they collectively agreed their gathering was a conspiracy: a political plot wherein women of African descent would engage in conversation, complicity, exchange, knowledge production, and political strategy (Vergara Figueroa and Arboleda Hurtado112). In this historical event, a group of women wrote a manifesto, which reads:

We make the case for conspiracy as a way to reject sexual violence against women; the reconfigurations of racism, sexism, and lesbophobia; and all forms of intolerance. We conspire because we claim a place of dignity in written, spoken, and artistic history. We want public policies and projects to include Black/Afro-descendent women as part of what counts as public. (120)

Voces de Resistencia is an act of Afrodiasporic conspiracy that claims a place of dignity in written, spoken, and artistic history, all the while demanding and making use of public funding and producing a project that centers on and includes Black/Afro-descendent women as part of the YouTube public media, as part of public intellectual projects, and as part of Colombian history, as well as Colombian and Afrodiasporic and Black feminist culture and thought, all of which count as public.

The fourth image in the first two minutes of the documentary also frames the Afrodiasporic conspiracy behind and represented by the documentary. In white font on black background, we read: "La comunidad de Pogue se ha dedicado a 
proteger y valorar el arte de los alabaos para quienes estos cantos representan la transición entre la vida y la muerte." This means that the documentary reminds the viewers that the Pogue community itself conspires by claiming its dignity in life and death, and in the transition from life to death.

The alabaos songs have been intentionally preserved in the Pogue community to protect and to value, to offer respect to all of the souls in between life and death, and to offer respect to all of those (living or dead) who understand what the alabaos represent. The songs serve as political chants of resistance while they recall the cultural connection to orality and the importance of collective mourning. At the same time, Black Women from the Chocó find in the alabao an obligation to use the song as politcal act of denouncing the State's injustice and their local history.

The dark background cuts to an aerial pan over a forest, and once again we are reminded of the location: ChocóColombia District, North Occidental Colombia, with a map, this time, superimposed over the forest-not a coincidental background. The location graphic fades out on the right side of the screen, and another graphic fades in on the left side of the screen, while the aerial pan shot over the forest continues: "Capital: Quibdó; Population: 542,960; Pacific Region." A woman's voice comes to the foreground of the soundtrack, singing a cappella. The generic information fades out, and at the bottom left, more precise demographic information appears, as a church and other buildings come into the pan aerial shot: "Population of African descent: $87 \%$ / 472,375; Indigenous: 9\% /48,866; Mixed: 4\% /21,718." The woman's voice sings the first song of the film, connecting the living and watching audience (the represented population in numbers on the screen) to the transitioning audience, and to those who have passed. A collective cinematic ritual of mourning and resistance begins.

\section{A Documentary Film Aesthetic Centered on Blackness, Femininity, and Ritual}

As the lead singer is joined with the chorus in the first song of call and response typical of the alabao, we reach the edge of the forest, and the first building we see is a church. To the bottom left of the church, an explanation of the local economy and the land: " $46,53 \mathrm{Okm}^{2}$; temperature above $27 \mathrm{C}$; economic activities: mining, forest exploitation, fishing, agriculture, ranching."

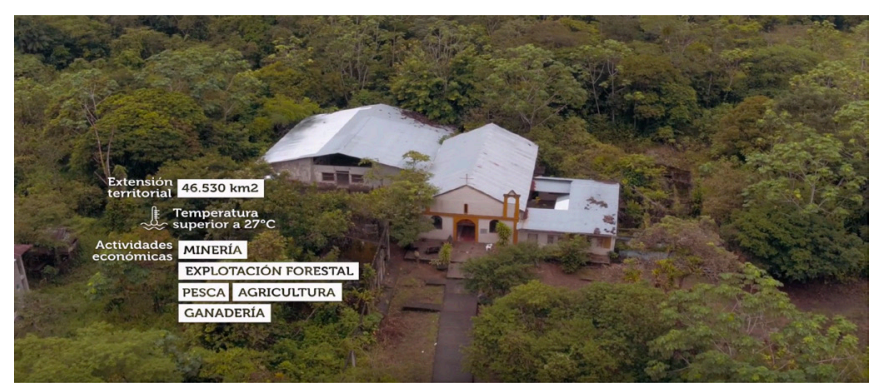

The aerial pan cuts to a different angle, a traveling shot, moving towards the main entrance of the church. The editing and focus of the beginning of the documentary, along with the lyrics of the alabao, clearly mark the spiritual components of what can be interpreted as an aesthetic of ritual of mourning. The traveling shot cuts to, finally, a static general shot, facing straight onto the subject of the image. A very large group of alabadoras and alabadores singers and songwriters, some sitting, some standing, face the camera, all wearing matching dresses and headwraps, the men in button up shirts and white hats. In the background, the ruins of their community (Quiceno Toro, et al 2017, 181-186).

The striking image is colorful, yet dark, and it reflects the nature of the alabao. As they sing the traditional song of ritual of transition from living to dead, we see the ruins of a massacre, and can imagine the spirits roaming, the bodies left behind, while, at the same time, the singers take all of the attention towards the spirit of song, and its healing powers.

What drives the camera to this point? Rufina Chaverra García is leading the traditional alabao "La Virgen Se Azará Mucho" with the same costume except for a blue necklace. The birds can be seen on the medium shot of Rufina, the same bird as the logo, as the dolls, as the species from the land from which they were torn away during the civil war. This is the first scene after the introductory credits, and it seems to lead to the massive group of Black women singers and their leader who gets the first close up as she sings the solo parts of the alabao.

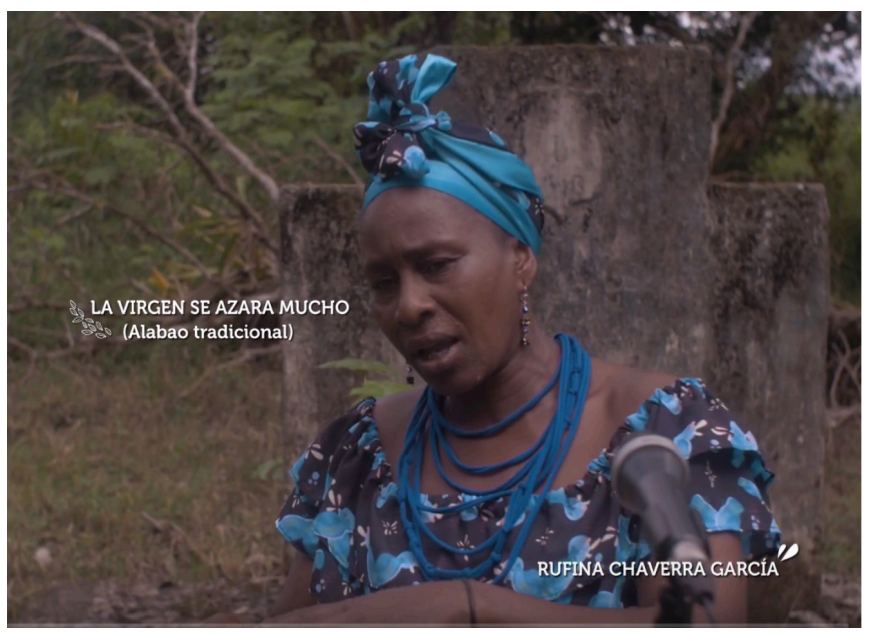

"La Virgen se azará mucho, cuando un alma va para allá sé que ha llegado un alma, sin Dios mandar la llamada...."

As they all sing about the tragedy of the children gone without God, calling for their lives to be over, and ask for the Virgin to take care of them; as sad as she was when Jesus was taken, she can take care of the little children who were called early to Heaven ("la Virgen se azará mucho, cuando un alma va pa'allá"). The camera pans across the group of 
alabadores, and in close ups of groups of three or four, we notice that aside from singing the lyrics, each singer mimics the meaning of the words. The gestures and embodied story, with the spiritual component of the story, complete the ritual of healing story-telling in another layer of witnessing. The song "Siempre Seas Bendito," composed by Ereiza Mosquera Palomenque, witnesses the following traumatic event:

"El día de (sic) de mayo, una pipeta cayó, a las diez de la mañana, la iglesia la destruyó, ... Bojayá lo condenaron... Y esto quedó en la oscuro, de la (sic) explotada, como corría en el agua, la sangre derramada...”

The witnessing of the trauma occurs through song, through lyrics, and through gestures for all audience members to understand the impact of the story, and to dignify those between life and death with a safe and respectful transition to the other side.

The song continues, and the images switch to filmed portraits, medium shots, not close-ups, that allow the viewer to "meet" each alabadora and alabador, and see more of the community in the background. The bulk of the documentary takes place on the ruins, and in the neighborhoods of the alabadores, and they are interviewed, asked about what they do, what the alabaos mean to them: "to conserve the tradition of our ancestors, today more than ever, we see how much this culture is worth conserving," says one of the abaladores.

The aesthetic of the film meets the ethical responsibility of conserving a tradition of a people that is target of genocide. Black women's femininity is represented with respect, they are shown as the center of the community. The faith that binds them and binds the songs and the tradition marks the aesthetic of the documentary, leading me to argue that Voces de Resistencia presents an aesthetic centered on Blackness, femininity, and ritual.

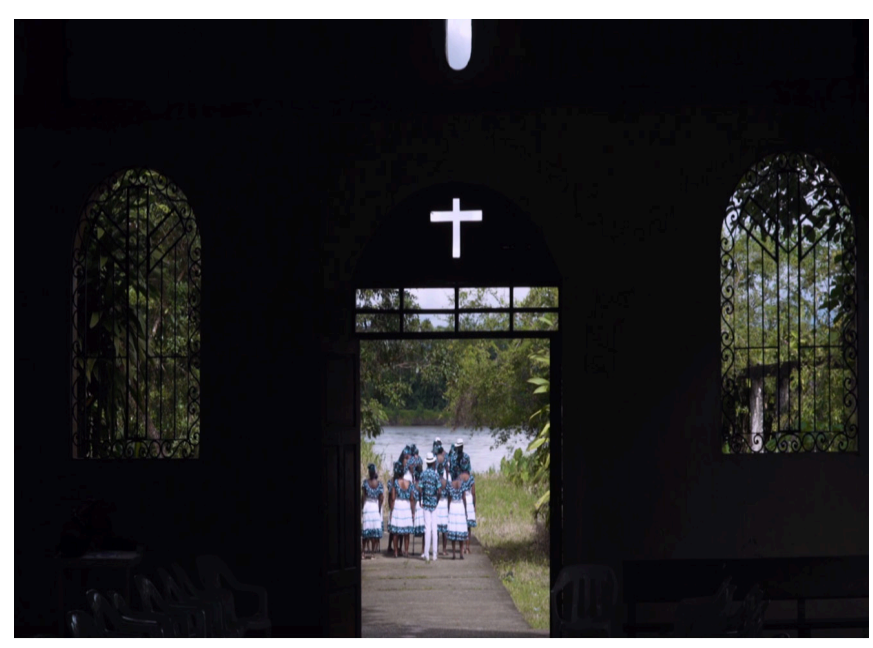

The centeredness includes nature, constantly in the background of every shot, quietly oppressed along with the
African descended peoples. The shot above exemplifies the aesthetic used throughout the documentary. On each side, a window open to the forest, with the green of the trees, stands as a stark contrast to the church's ruins. The cut out of the cross in the center of the image and the top of the church allow the sky and sunlight to pierce through. We can see the water, and some palm trees in the background, yet not faded away; they are placed strategically in the composition to have enough of a presence. Finally, the women's white skirts have to be noticed in any setting, as a body of sanctity; striving to resist among ruins and lost souls, the women are very much alive, and well, and singing loudly.

Each scene is paced by a song, and centered by a lead singer. A close-up of the lead singer lets us see her adornments: her head wrap, earrings, bracelets, rings, and a firmly focused gaze punctuated by the spiritual trance of chants.

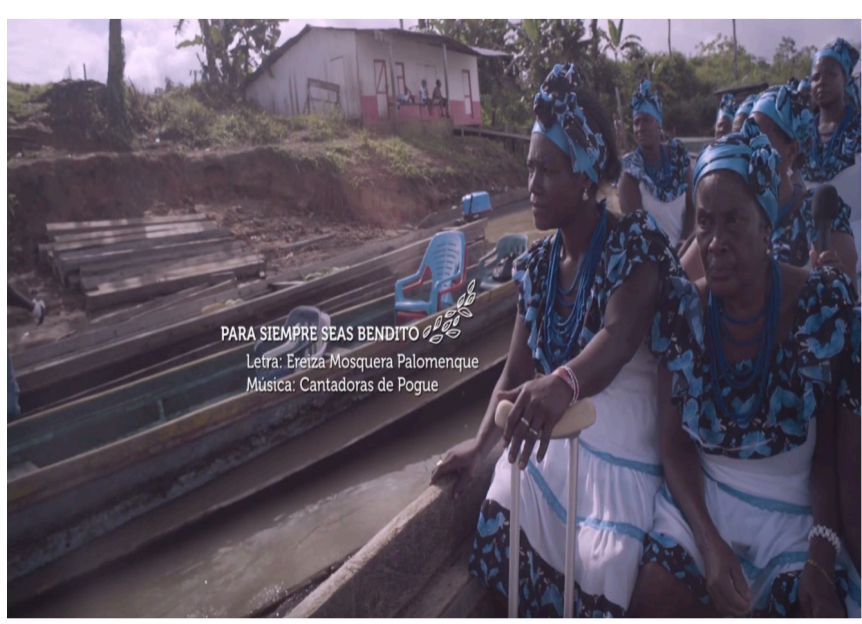

"Cómo corría el agua, de la sangre...." How the blood flowed in rivers....

\section{An Audiovisual Cinematic Witnessing That Heals Communal Trauma}

This next scene in the documentary mourns while critiquing and calling the State for its neglect and the injustice against a community of hardworking peasants. The images do the work of mourning visually, while the alabadoras sing, on a fishing boat, a song of their own creation: "Para Siempre Seas Bendito." "May You Be Blessed, Always" has a cynical moral and an antithesis to call on those who have not blessed the community, and instead have punished them unfairly: those who came onto the land of the workers and peasants and massacred innocent civilians; and those who silenced the traumatic massacre in Bojayá.

The Cantadoras de Pogue provide a history lesson with morals of equity and resistance in the face of class and racebased oppression. After the first stanza, the lyric explains: "We the peasants have been mistreated, we paid the heaviest price"-meaning that in the class struggle for land rights 
and drug market ownership, they had to pay with their lives and got nothing in return. The alabadoras go on to ask: "Respect our rights and stop violating our rights; on our own land, you come to massacre our people?!” The lyric reinforces how their nation functions with a logic that fits the genocidal neoliberal regime; still frames of the church that was bombed are shown while the song continues. One of the images depicts the list of names of all who died during the bombing, printed on a colorful fabric, hung in the church. We see empty chairs, where church goers once sat, and where on a later date, government "leaders" would come to perform a political charade of an apology, to ask for the Bojayá community's forgiveness. This is not a lesson in helplessness, and this community has no affective need of closure from government leaders. They know what their purpose is here, and they clarify it as the song builds to an important message on accountability: "To all of the presidents, you better keep your word; what happened in Bojayá better not happen again." The chorus repeats and emphasizes that they will hold their leaders accountable:

They better receive their punishment

We have been mistreated, us, the peasants, and paid the most violent price

Respect our rights; do not violate our rights, They came to our own land, and massacred us. Presidents, you better be honest,

And claim that what happened in Bojayá, will not happen again.

"Para Siempre Seas Bendito," Oneida Orejuela, 2014.

With poetically stunning movements, the camera pans towards and around abandoned structures: a school, a nursing station, a church, each building more strikingly void of human presence. The vines, trees, and moss, covering over the cement that has been left behind, emphasize the institutional abandonment and need for access, equity, redress of genocidal practices. The images show the consequences of the state-mandated violence, while the chants describe and mourn the lives lost, and condemn the State and the justice system. At this point, two female alabadoras describe how much, to them, the alabao serves a political purpose.

The singer-songwriters go on to call on those in power to own up to their cruel neglect: presidents, soldiers, and the press.

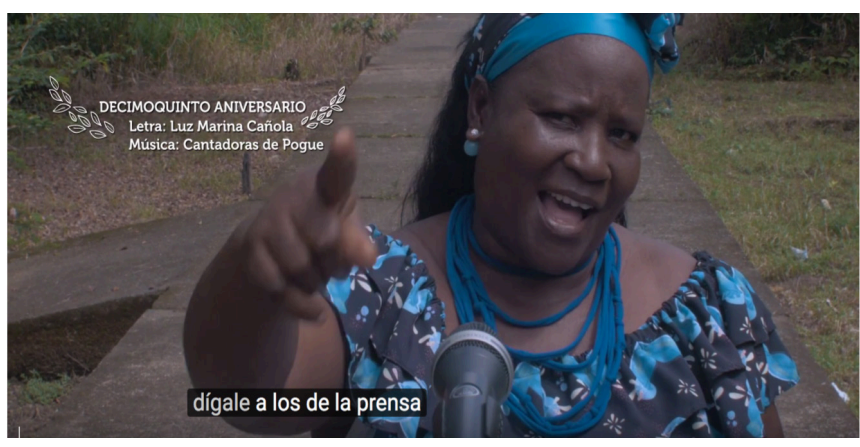

"Don't you ever come back here."

In "Décimoquinto aniversario," (15 $5^{\text {th }}$ Anniversary) a lyric by Luz Marina Cañola, the Cantadoras de Pogue emphatically declares that the press cannot erase their memory. The massacre of their community will never be forgotten, they claim, it remains a part of history. Then they address the men of the armed groups: “Don't you ever come back here.”

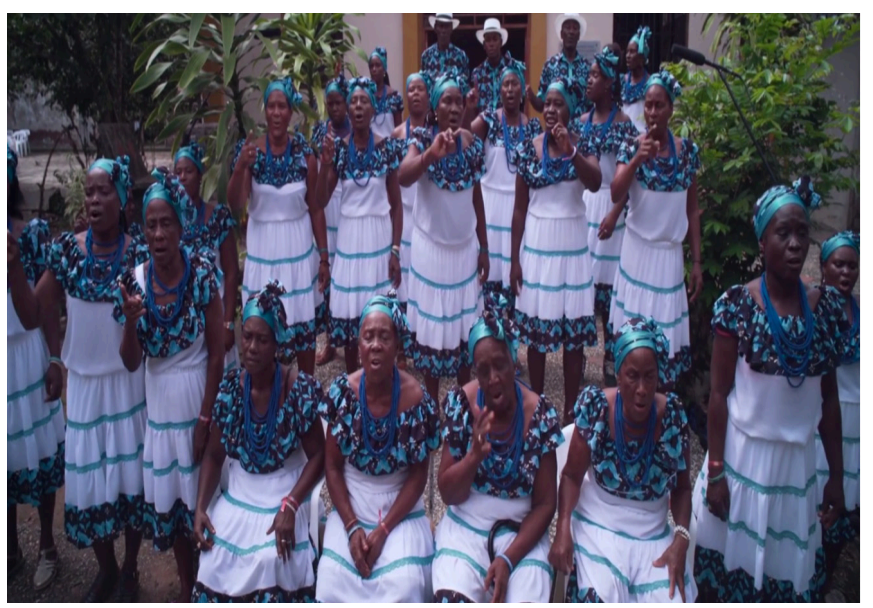

"Sirs, with your armed groups, don't you ever come back here. We are tired of singing about you. Stop the violence in the Bojayá region."

Aside from the direct claims and assertiveness, they remind their audience that though children are the future, in their situation, the future was killed. The lyric implores, "Why did our children have to die?" The chant answers, "Because they are workers and peasants." The lesson in class struggle continues, and once again the song reinforces how their nation functions with a logic that fits the genocidal neoliberal regime, this time with the press as a consenting party in the regime: "This was a hit, a hard hit, that terrorized all of us. They created this war, and the peasant was the one who suffered." "They" remains undefined, and the war is depicted as an irrational and cruel event; with striking hand gestures and the use of the demonstrative pronoun "esta Guerra."

At the end of the song, they address their attackers-“Señores"-directly, but also address History and, in 
turn, epistemic justice: "And this, goes into history, and will never be forgotten. Sirs, with your armed groups, don't you ever come back here. We are tired of singing about you. Stop the violence in the Bojayá region." The assertive chant leads to the next scene, with images of the community that continue to live on, neighborhoods, young adults walking and smiling in the streets, the future, and the hope for the future that remains alive. Two alabadoras explain the role of the alabao has changed: "Because of the State's abandon of our region and all of the violence, we decided to compose, as women, lyrics that denounce the violence of our communities. We have to let the world know how terribly we have been hit by the cruelties of war. We sat down, as women survivors of the violence, and wrote songs." "The alabao has made our stories more famous; it's no longer a familial ritual."

A ritual of mourning originally conceived for families has become collective and global in the context of hypercapitalism and state violence ignored nationally and globally. The healing becomes collective for the community as they, alabadoras' words, are punctuated by a vertical pan shot of the next soloist, who stands on one leg, survivor of the violence, composer of "Santa María Dadnos La Paz," Ana Oneida Orejuela Barco sings to the Virgin Mary to offer peace, or that the peace treaty go well.

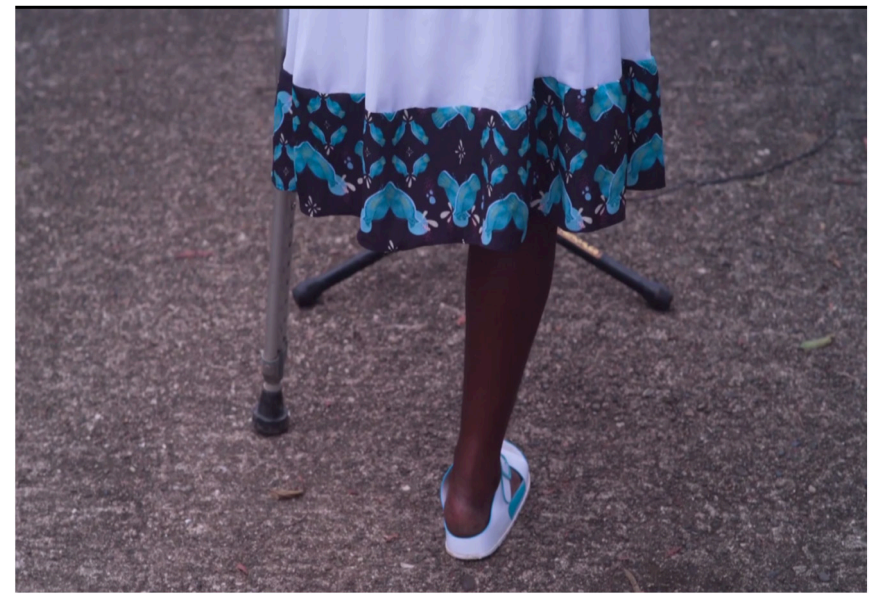

"We ask that peace and education reach our lands."

"We report with joy that the FARC guerrillas will put down their weapons. They didn't let us fish, or work," the group sings, and advocates for peace, and explain that with peace would come labor, education, and the freedom to work: "We ask that peace and education reach our lands." In other words, peace would provide them with their basic rights, and improve their stifled economy. The group is filmed in the same aerial shot from the beginning, as they slowly walk into the church at the edge of the forest. The end is bitter, not sweet, since some of us in the audience know, that as much as they felt joy to share the news of the peace treaty in the song, their communities have remained a target of kidnapping, planned assassination of community leaders, young black men's deaths, and altogether a continuation of the State's neglect, now paired with eco-genocide, the pollution of the River Arroyo, the lands limited to coca leaf monoculture, etc.

The sound fades back to the quiet crickets of the very beginning of the film, and the image aesthetic returns to the declaratory tone of the beginning of the documentary: "The alabaos were declared Immaterial Patrimony of the Colombian Nation by the National Council of Patrimony in August 2014." The cricket sounds fade out and the credits run, showing the names of each of the alabadoras and alabadores, along with the institutions that contributed to the production, including the Center for Democracy and Ethics, the Center for Afrodiasporic Studies, the ICESI University, and the Ford Foundation.

\section{Public Funding, University Funding, Local Economy, and Black Women}

With grants received from the Ford Foundation, the university, departments, and personal funding, the production team spared no expenses-it was important to use the best equipment and best conditions with the least disturbance to the lives of the women of Bojayá. With this in mind, the film production team brought their very best microphones, and recorded multiple times on location. The costume designer Claudia Patricia Buitrago hand designed each costume. The resources also trickled down to support the community's economy. For example, they used grant funding to pay for the groceries and the labor that went into cooking meals for the production team in Bojayá. The funding went directly to community members and fed the local economy. And at each stage of the production, the singer-songwriters gave their input.

"The project involved many layers of our lives, many people, a lot of reflection, discussion, revisions..." and for that reason, Vergara Figueroa states, it is really quite lovely to think of the project as a holistic form of Black feminist intellectual activism. Throughout the interview, she gave me several examples of the multilayered components of the project that, indeed, made it holistic, and Black feminist, intellectual activism. For example, in order to distribute the funding, she turned to the women and asked them, "What would you like to do, and how would you like to do it?" And from their needs and their perspectives, she started to plan the budget of the project.

In terms of the logistics and planning of the project, a level of trust among Black women was central to the development and management of Voces de Resistencia: Capitulo 1. The team visited the communities multiple times, for different reasons, one being that in the context of violence, Black women play the role of gatekeeper, or "Bisagra." They are the 
point of communication for whoever enters, from outside, and whoever lives in the community. And they protect their loved ones.

The gatekeepers received the best equipment, and to make a statement on the equipment used for them, the boom microphones were left in many of the large group shots, and some of the close-up shots include a microphone on a stand. The sound recording and the songs were also done in a living room turned into a sound booth, with the best equipment they could travel with, to produce a high-quality LP of the original score and some traditional songs. The Ford Foundation grant, the ICESI University funding, and the Afrodiasporic Center's funds-U.S. Federal, Colombian, and institutional monies-all fed into the lives of the Bojayá women and their families. They were exposed to a level of respectability that continued the dignity work they were already doing with their songs. The production turned into an Afrodiasporic feminist conspiracy that supported the existing Bojayá feminist conspiracy.

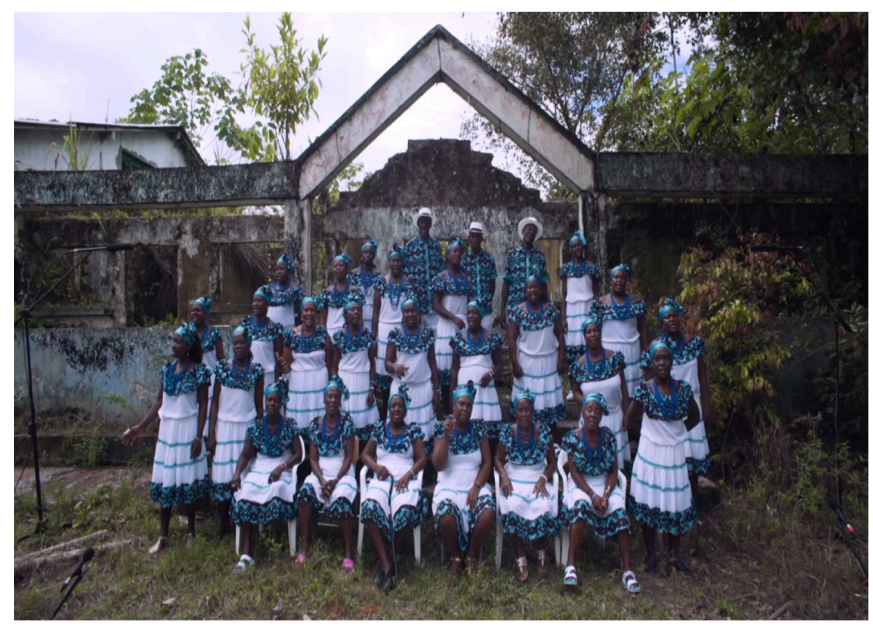

For the premiere of the documentary, open to the public, a large portion of funding needed to be secured for the entire group of singers to fly, many of them for the first time, stay in a nice hotel, where they could also receive the best treatment as Black Colombians-this was not easy to find in Cali. And so, from the macro mechanisms of applying to federal grants, to the micro negotiations in gazes with the hotel staff that determined a need to change hotels and support a business that would not be covertly racist, the multimedia project Voces de Resistencia quickly became a long-term enactment of holistic Black feminist intellectual activism. A future article on this topic will unveil the full interview with Dr. Aurora Vergara Figueroa to uncover more strategies on how to negotiate the academy, public funding, and participatory research with African-descended communities.

\section{Conclusions}

The short documentary film promotes self-definition as community members took part in the production, and self-determination as it portrays Black female community members as agents of their history. In different songs, it is clear that the alabadoras have a multi-dimensional function in their community: they call attention to erased parts of history, denounce injustice and governmental neglect, and recall the important lives of their loved ones. As a whole, the act of songwriting and performing creates an embodied response that heals the traumas of state-mandated violence, and addresses the depth, breadth, and reality of genocidal wounds. The documentary embraces the aesthetic of the alabao folklore, an art handed down generations that channels ancestral wisdom, creativity, and resistance. The analysis of the documentary notes the connection to nature, spirit, and emphasis on Black women's agency and community-building, thus demonstrating a Black feminist critique of film. The laser-focused details and consistent care in the production of Voces de Resistencia led to a production in line with Afro-Latin American scholarship that supports and engages our communities towards self-definition and self-representation, honoring the ways that Sojourner Truth, Harriet Tubman, Dandara, Aqualtune, and other foremothers who walked the lands. In the face of genocide, there are multiple ways to resist: in film, in higher education, through song, in the community, in our kitchens, with Ford fellowships to sustain our economies, to redress the narratives that have silenced us, voices of resistance call out the inhumane practices of the government and the press censorship, and raise fists against epistemic violence. On various levels, despite what has happened, we will not forget and we will not give up, damn it, \#elpueblonoserindecarajo. 


\section{NOTES}

1. The introduction to Afro-reparaciones: memorias de la esclavitud y justicia reparativa para negros, afrocolombianos y raizales (2007), Descolonizando Mundos (2017), Demando mi libertad (2018) present the current state of suppression and omission of Afro-Colombian intellectual, political, and artistic production, including the omission of women's work in each field (Vergara Figueroa et al. 14; Chaves Maldonado 19)

\section{WORKS CITED}

Arboleda Quiñones, Santiago. “Afrocolombianos: El ecogenoetnocidio más grande de las Américas.” Empire and Its Aftermath: Transhispanic Dialogues on Diaspora. Conference Presentation, April 3-5 2019.

--. "Conocimentos ancestrales amenazados y destierro prorrogado: la encrucijada de los afrocolombianos." Afro-reparaciones: Memorias de la Esclavitud y Justicia Reparativa para negros, afrocolombianos y raizales. Claudia Mosquera Rosero-Labbé \& Luiz Claudio Barcelos, eds. Bogotá: Universidad Nacional de Colombia, 2007. 467-489.

Butler, Kim. Freedoms Given, Freedoms Won: Afro-Brazilians in Post-Abolition Sao Paulo and Salvador. New Brunswick, New Jersey, and London: Rutgers U Press, 1998.

Cañola, Luz Marina. “Décimoquinto aniversario.” Voces de Resistencia Capítulo 1. 2017

Davis, Angela Y. Women, Race, and Class. New York: First Vintage Books, 1983.

Hill Collins, Patricia. Black Feminist Thought: Knowedge, Consciousness, and the Politics of Empowerment. New York and London: Routledge, 2000.

Orejuela, Oneida. "Para Siempre Seas Bendito.” Voces de Resistencia Capítulo 1. 2017.

Orejuela Barco, Ana Oneida. "Santa María Dadnos la Paz," Voces de Resistencia Capítulo 1. 2017.
Palomenque, Ereiza Mosquera. "Siempre Seas Bendito.” Voces de Resistencia Capítulo 1. 2017.

Quiceno, Natalia; Ochoa Sierra, María y Villamizar, Adriana. "La política del canto y el poder de las alabaoras de Pogue (Bojayá, Chocó).” Estudios Políticos (Universidad de Antioquia), 51, July-Dec. 2017. 175-195.

Vergara Figueroa, Aurora. Afrodescendant Resistance To Deracination In Colombia Massacre At Bellavista-BojayáChocó. Palgrave-Macmillan, 2018.

--. Personal Interview. 19 Jan. 2019.

Vergara Figueroa et al. Antologistas. Descolonizando Mundos: Aportes de intelectuales negras y negros al pensamiento social colombiano. Ciudad Autónoma de Buenos Aires, CLACSO, 2017.

Vergara Figueroa, Aurora \& Katherine Arboleda Hurtado, "Afrodiasporic Feminist Conspiracy: Motivations And Paths Forward From The First International Seminar." Meridians: Transnational Feminisms, 2016. 118 - 126.

Vergara Figueroa, Aurora \& Carmen Luz Cosme Puntiel. Demando mi libertad: Mujeres negras y sus estrategias de Resistencia en la Nueva Granada, Venezuela y Cuba, 17001800. Cali: Universidad Icesi, 2018.

Varón, José. Dir. Voces de Resistencia: Capítulo 1. Fenómena Fotogramas, Cali, Colombia, 2017. 